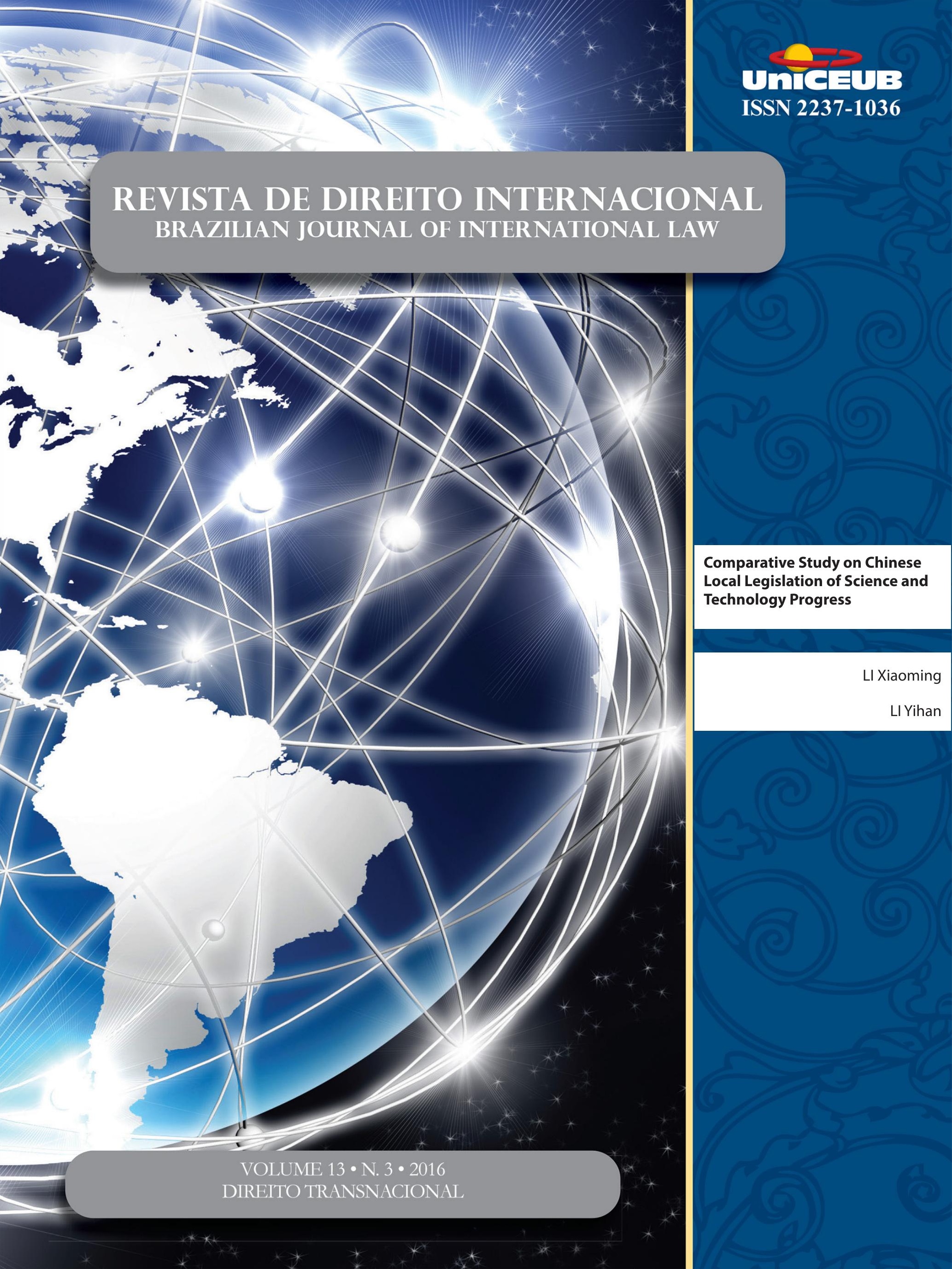


Crônicas da ATUALIdAde do direito internacional .................................................. 2

I. Dossiê Temático: Direito Transnacional .........................................................15

EDITORIAL: O Direito Transnacional - Circulação de normas e relações jurídicas transnacionais .......16 Priscila Pereira de Andrade

A emergênCia do direito transnacional ambiental .............................................18 Priscila Pereira de Andrade

Desafíos y RESPUESTAS TRANSNACIONALES FRENTE A LOS CRÍMENES AMBIENTALES ...............30 Rosmerlin Estupiñan-Silva

DiREITO TRANSNACIONAL E MUdANÇAS CLIMÁTICAS .50 Géraud de Lassus Saint-Geniès

Especies en movimiento: la Convención sobre el Comercio Internacional de Especies Amenazadas de Fauna y Flora Silvestres como espacio de “Encuentro” de discursos, ACTORES Y ESTRATEGIAS EN EL DERECHO AMBIENTAL TRASNACIONAL

María Valeria Berros e Dabel Leandro Franco

El carácter transnacional del Sistema comunitario de ECogestion « Eco-ManageMENT AND Audit SCHEME » (EMAS) DENTRo de LA UE y MÁs ALlÁ DE SUS Fronteras ......72 Adélie Pomade

O CONCEITO DE CONDUTA EMPRESARIAL RESPONSÁVEL À LUZ DOS ORDENAMENTOS JURÍDICOS BRASILEIRO, INTERNACIONAL E TRANSNACIONAL

Gabriel Webber Ziero

ARBITRAGEM NO DIREITO TRIBUTÁRIO INTERNACIONAL E NO DIREITO INTERNACIONAL DOS INVESTIMENTOS: UMA MANIFESTAÇÃO DO DIREITO TRANSNACIONAL

Vivian Daniele Rocha Gabriel 
O DIREITO TRIBUTÁRIO SOB UMA PERSPECTIVA TRANSNACIONAL

Franciele de Simas Estrela Borges

As Características do Direito Transnacional como Metodologia: Análise sob o enfoQue dos Aspectos Processuais da Arbitragem 126

Flávia Foz Mange

O DIREITO TRANSNACIONAL (“GLOBAL LAW") E A CRISE DE PARADIGMA DO ESTADO-CENTRISMO: É POSSÍVEL CONCEBER UMA ORDEM JURÍDICA TRANSNACIONAL? ...................................... 146

Luiza Nogueira Barbosa e Valesca Raizer Borges Moschen

TransPorte AÉREO E DIREITO TRANSNACIONAL: DA CONVERGÊNCIA À UNIFORMIDADE 160 Mickael R. Viglino

Outros Artigos. 175

O Fundo Monetário Internacional e a proteção dos direitos humanos: uma análise DO PROGRAMA DE CRESCIMENTO E REDUÇÃO DA POBREZA NO HAITI 177

Pablo Henrique Hubner de Lanna Costa e Carlos Alberto Simões de Tomaz

Um estranho no ninho? Padrões privados no Acordo de Barreiras Técnicas ao CoMÉRCIO DA OMC 192

Michelle Ratton Sanchez Badin e Marina Yoshimi Takitani

Os benefícios tributários do programa Inovar-Auto e os princípios da Nação Mais Favorecida e do Tratamento Nacional: uma análise dos argumentos dos Painéis atualmente em Curso contra o Brasil no Órgão de SoluÇão de Controvérsias da OMC . 211 Eric Moraes Castro e Silva

A ERA DA HUMANIDADE: REFLEXões PARA A HISTÓRIA DO DIREITO INTERNACIONAL 236 Henrique Weil Afonso

Precedentes vinculantes nos Estados Unidos da América e no direito brasileiro: Um ESTUDO COMPARADO 264

Patrícia Perrone Campos Mello 
IL DIRITTO AMBIENTALE SECONDO L'OTTICA DEL DIRITTO COSTITUZIONALE POSITIVO E LA RESPONSABILITÀ PER DANNI ALL'AMBIENTE NEL DIRITTO COMUNITARIO: LO STATO DELL'ARTE DEL DIRITTO AMBIENTALE COSTITUZIONALE E COMUNITARIO 287

Elcio Nacur Rezende

DA DESCONSIDERAÇÃo DA PERSONALIDADE JURÍDICA NAS RELAÇÕES CONSUMEIRISTAS BRASILEIRAS: ANÁLISE À LUZ DAS TEORIAS CLÁSSICAS

Daniel Amin Ferraz e Marcus Vinicius Silveira de Sá

ANALYSIS OF ADVANTAGES AND DISADVANTAGES OF FORUMS PRESCRIBED UNDER THE UNCLOS AND STATE PRACTICE: THE WAY AHEAD FOR INDIA ......................................................319

Vinai Kumar Singh

Do governo POR LEIS À governanÇA POR NúMERos: breve anÁlise do Trade in SERVICE AgreEMENT (TISA) ...............................................................................338 Jânia Maria Lopes Saldanha, Rafaela da Cruz Mello e Têmis Limberger

As DIRETIVAS EUROPEIAS COMO NORMA REGULADORA DO DIREITO ADMINISTRATIVO GLOBAL ..356 Alice Rocha da Silva e Ruth Maria Pereira dos Santos

O desenVolvimento da POlítica AGRícola COMUM dA UNião EUROPEIA 375 Tatiana de A. F. R. Cardoso Squeff

A imunidade de Jurisdição das organizaÇões internacionais FaCE AO Direito de aCESSO À JUSTIÇA 391

Fernanda Araújo Kallás e Caetano

O DIREITO INTERNACIONAL ENTRE O DEVER ÉTICO E A AÇÃo POLÍ́TICA: OS FUNDAMENTOS DE UM DEVER DE COOPERAÇÃO INTERNACIONAL NA FILOSOFIA POLÍTICA DE IMMANUEL KANT .405 Ademar Junior Pozzatti

EXTENSÃo E FRAGMENTAÇÃo NO CONTEXTO DA JURISDIÇÃO PENAL INTERNACIONAL .423 Marcus Vinícius Xavier de Oliveira

A DEFINiÇÃo JURÍdiCA DA "COMUNIDADE" .444 Nitish Monebhurrun, Michelle Lucas Cardoso Balbino, Fernanda Castelo Branco Araujo, Othon Pantoja, Míara Bogo Bruno e Cândida Dettenborn Nóbrega 
Comparative Study on Chinese Local Legislation of Science and Technology ProGRESS

LI Xiaoming e LI Yihan

O CONTROLE PENAL DO TRÁFICO DE PESSOAS: CONSTRUÇÃO JURÍDICA, INTERAÇÕES ORGANIZACIONAIS E COOPERAÇÃO INTERNACIONAL

Bruno Amaral Machado e Priscilla Brito Silva Vieira

Desativismo judicial: a extradição Battisti no Supremo Tribunal Federal .505 Francisco Rezek e Israel Paulino

A decisão norte-americana do Caso Myriad: novos paradigmas para a Proteção patenTÁRIA DO CÓDIGO GENÉTICO HUMANO E BIOTECNOLOGIA 514 José Carlos Vaz e Dias e Clarisse De La Cerda 


\title{
Comparative Study on Chinese Local Legislation of Science and Technology Progress*
}

LI Xiaoming ${ }^{* *}$

LI Yihan***

\begin{abstract}
With the amendments of the "Scientific and Technological Progress Law of the People's Republic of China" in 2007, People's Congress at all levels that have legislative power have revised and created new ordinances in line with the law. Comparing the local scientific and technological progress ordinances that have been subsequently revised, discussing the merits and defects of the composition and content in each and summarizing how to make guiding ideology, revised main body, legislation technique, clause content and ordinance composition, has a significant positive impact on the implementation of national law and for the achievement of valid and rational local legislation.
\end{abstract}

Key Words: Science and Technology Progress, Local Regulations, Scientific and Technological Progress Ordinance

\section{INTRODUCTION}

Prior to December 29, 2007, there were 48 science and technology progress ordinances in China. ${ }^{12}$ From this date to Sept. $30^{\text {th }}, 2015$, there have been 23 ordinances legislated or revised by the People's Congress at the provincial level and 13 at the city level. These authors suggest that amending and upgrading ordinances is beneficial to scientific and technological progress.

This article compares, and analyzes the advantages and disadvantages of the content differences among these 36 ordinances to supply the reference for future legislative experiences. ${ }^{3}$

The People's Congress, at both the provincial and city levels, utilized

* Recebido em 17/12/2016

Aprovado em 21/12/2016

** Li Xiaoming, lecturer of Xi'an Jiaotong University School of Law Post-doctoral Researcher, and post-doctoral researcher of the Research Center of Business Administration in Xi'an Jiaotong University School of Management.

*** Li Yihan, graduate student of Renmin University of China, who has obtained bachelor's degree in Law and double bachelor's degree in economies of Xi'an Jiaotong University. E-mail: Li, Xiaoming"<li549@iu.edu
1 All the data of revised laws and regulations in this thesis are collated and selected by the authors, according to the website: "China law info.". (Oct. 30th, 2015) http://www.chinalawinfo.com/. In this thesis, all statistics are not included for Hong Kong, Macao or Taiwan. 2 The 48 science and technology progress ordinances in China had been legislated or revised by local People's Congress, before the amendments of "Scientific and Technological Progress Law of the People's Republic of China" (hereinafter referred to as "Scientific and Technological Progress Law")on Dec. 29th, 2007.

3 On the one hand, there are 32 People's Congresses at the provincial level, of which nine legislative institutions have not revised regulations about scientific and technological progress. On the other hand, the Legislation Law of the People's Republic of China (2015 Amendment, March 15) has enlarged the number of the cities, which have local legislation authority, from 49 to more than 280. This means that more than 200 People's Congresses at the city level would develop the regulations about promoting scientific and technological progress. 
two methods to develop scientific and technological progress laws. ${ }^{4}$ One is to make amendments to the primary scientific and technological progress law. Xiamen revised the "Scientific and Technological Progress in Xiamen Special Economic Zone Ordinance" through implementation of the "Scientific and Technological Progress Law" on July $1^{\text {st }} 2008$, obtaining a higher evaluation of the both technology and legal domain. This harmonization between the old lower-level law and the new higher-level law increased validly. Shenyang, Hefei, Hubei and some other Provinces utilized this same approach. Another situation is creatively formulating regulations of science and technology out of an urgent need to develop new local science and technology policies. Three examples are implementation of the "Shenzhen Special Economic Zone Scientific and Technological Innovation Promoting Regulations" (effected from October $\left.1^{\text {st }}, 2008\right)$; the "Kunming Scientific and Technological Progress and Innovation Regulations" (effected from January 1st, 2009); and the "Guizhou Province Scientific and Technological Progress Regulations" (effected from January $1^{\text {st }}, 2010$ ).

Judging from the appellation of these new regulations, the enacted ordinances mostly in the constitution of "place name" attaching "Scientific and Technological Progress Regulations", like "Scientific and Technological Progress Law of the People's Republic of China". Comparatively, the newly enacted ordinances in the Ningxia Hui Autonomous Region and the Tibet Tibetan Autonomous Region are called the "Implementation Approaches of People's Republic of China Scientific and Technological Progress Law" because of the less more specific measures than the ordinances and the much same structure as the host law. Legislators in Ningxia abolished "Regulations" intentionally replacing them with "Implementation Approaches". It's worth noting that Shenzhen, Kunming and Chongqing applied the word "innovation" explicitly into their written titles. This action achieved higher requirements and standards than the term "progress" alone implies. "Progress" means that the scientific and technological level is increased from low to high, no matter how limited the degree of improvement, or wherever the absolute level of the increased one lie in. Conversely, the "innovation" must be "original inventions". The "innovation" means

4 This indicates the 23 People's Congresses at provincial level and 13 People's Congresses at city level, which have legislated or revised ordinances from Dec. 29th, 2007 to Sep. 30th, 2015. the new achievement is more advanced than the former highest level. Emphasis on original innovation within the China's national core strategy, elevated the ability of independent innovation and established an innovative prosperous country. Semantically, usage of the word "innovation" focused on technology innovation, corresponding to the legislative purpose of scientific and technological progress ordinances. Therefore the term of "innovation" is more accurate.

From the facet of structure, with the exception of the "Shenzhen Special Economic Zone Technological Innovation Promoting Regulations" and the "Dalian Scientific and Technological Progress Regulations" that don't involve chapter's partition, other newly enacted ordinances are adapted to the "Scientific and Technological Progress Law" systematically. ${ }^{5}$ Although the heading of each chapter is expressed in different ways, each is basically about the general, development and application of science and technology, -- more specifically, bodies of science and technology activities (including enterprises, research institutes and technical personnel), safeguard measures, legal responsibilities and supplementary parts. In addition, some local legislators adjust the order of chapters or delete some content according to each province's characteristic development of its science and technology programs. For example, the "Kunming Scientific and Technological Progress and Innovation Act" involves special Chapter III "innovation system establishment" corresponding to the legislative purpose and appellation. Additionally, "scientific and technological resource sharing and service building" was made a separate chapter in the "Shandong Scientific and Technological Progress Regulations", emphasizing integration thereby making full use of scientific and technological resources to achieve progress.

Overall, the chapters' arrangement of freshly revised ordinances reveals two distinct trends compared to legislation before 2007. One is more compact, paying attention to local characteristics, such as new rules in Ningxia that reduced more than 10 provisions. Another is more ample, focusing on the addition of new initiatives to promote technological progress. These authors prefers the former mode, which is a more sim-

5 The "Shenzhen Special Economic Zone technological innovation promoting Regulations" isn't divided into chapters or sections, but only directly lists 23 clauses. "Dalian Scientific and Technological Progress Regulations" also is not divided into chapters or sections, but totally includes 31 clauses. 
plified chapter arrangement, because the purpose of local regulations' legislation is to make the scientific and technological progress ordinances more workable and more in line with local conditions. This article compares the strengths and weaknesses of each local regulation, chapter by chapter, and then brings forward proposals on the macro-structure and provisions of the content.

\section{Comparative analysis of Key provisions in LOCAL LEGISLATION OF SCIENCE AND TECHNOLOGY PROGRESS}

Under the guidance of legislation science, the reference of "Scientific and Technological Progress Law" and other relevant laws, this article develops a comparative analysis of key provisions in the local legislation of science and technology progress. It does so taking into consideration the matter in which the provisions are combined with the specific circumstances of the local technology and what significance each may bring to the future legislation.

\subsection{Comparative Analysis of General Provisions}

Normally General Provisions of science and technology progress legislation include legislative purpose, legislative basis, basic concepts, the responsibility scope of the local people's government and administrative departments, the core policies of the local science and technology, etc. This paper selects three aspects to analyze General Provisions: (1) legislative purpose, (2) government and administrative departments' responsibility, and (3) scope and examination systems.

\subsubsection{Legislative purpose.}

The 36 local legislations of science and technology progress, most utilize the phrase "to promote or facilitate scientific and technological progress", and more or less repeat the legislative purpose of the "Scientific and Technological Progress Law". The "Shenyang Scientific and Technological Progress Regulations" do not specify the legislative purpose; while the "Chongqing Scientific and Technological Innovation Promoting Rules" deepens the legislative purpose of its "Scientific and Technological Progress Law", highlighting innovation and local development requirements, which are described "to facilitate technological innovation, to promote scientific and technological achievements industrialization, to raise the city's core competitiveness." Local legislation serves as a tool to both help the enforcement of abstract higher-ranking law and boost local science and technology progress. Its basic premise is consistency with the higher-ranking law in legislative purpose. It clarifies local characteristics. In conclusion, the expression of legislative intent in the "Chongqing Scientific and Technological Innovation Promoting Rules" would be more scientific and reasonable.

\subsubsection{Government and administrative depart- ments' responsibility scope.}

Lots of regulations state that local development planning should be formulated, in order to make scientific and technological progress more definite. Especially worthy of recognition, is revising the procedural and explicit content of the local planning as illustrated in Shenzhen's regulations. ${ }^{7}$ The provocations worked out responded to the characteristics of each location, such as the "Xi'an Scientific and Technological Progress Regulations", which states that typical development zones and industrial base management committees are responsible for the scientific and technological progress within their domain. This is significant in that Xi'an has multiple types of development zones and industrial bases, ${ }^{8}$ which define the responsible areas between government departments and administrative departments, and to avoid conflict of authority or potential power vacuums. The contents, drawn up to refine the abstract higher-ranking law, need to be noted. For instant, the third paragraph of Article II in the "Xiamen Special Economic Zone Scientific and Technological Progress Regulations" involves "governments at all levels must establish and complete the scientific and technical advisory system", which details scientific decision making in Article XIII of "Scientific and Technological Progress Law". Last, but not least, innovative content such as the "science and technology administrative department in Shanghai shall prepare an annual report on the progress

\footnotetext{
6 Article 1, "Chongqing Scientific and Technological Innovation Promoting Rules".

7 Article IV, "Shenzhen Special Economic Zone scientific and technological innovation promoting Regulations".

8 Article III, "Xi'an Scientific and Technological Progress regula-
} tions". 
of science and technology," nicely summarizes the achievements and correct deviations during scientific and technological advancement.

Meanwhile, improper authorization should be diverted. For example, the "Hefei scientific and technological progress regulations" states that "the relevant departments take charge of work in technological progress from their duties under the operational guidance from science and technology administrative departments of the same level." ${ }^{10}$ This expression could be understood to mean that the relevant departments shall, under certain conditions, accept the guidance and enlarge the authority of the administrative department of science and technology. This is because given the current organization of the administrative system nationwide, there is only operational guidance towards specific technology activities between same grade administrative departments rather than overall operational guidance.

\subsubsection{System of examination and assessment.}

System of examination and assessment is key to ensuring the advancement of scientific and technological progress. The vast majority of local legislation contains the related provisions except the "Shenzhen Special Economic Zone Technological Innovation Promoting Regulations". "Scientific and Technological Progress Law" only divides technological achievement into the scope of examination and assessment to the people in charge of state-owned enterprises while multiple regulations detail the content around assessing objects and examining items. Including an evaluation of how local governments and their departments work towards technological advancement, or how they use the technological innovation financial funds to establish scientific and technical research institutions and its effect, or how well the technology staff delve into technology exploitation, or the assessment of farmers' professional skills, in addition to the assessment to science and technology investment and rating to local skilled workers would strengthen such legislation. Apart from the chapter-general provisions, regarding the system of examination and assessment, appears in multiple chapters, even it is drafted into a separate chapter in "Hefei Scientific and Technological Progress Regulations" ${ }^{\prime 11}$ with the chapter of encourage and reward.

By comparison, these regulations could enlighten us. The system of examination and assessment in the "Hefei Scientific and Technological Progress Regulations", towards the people's government, is illustrated at the township level. It states that "the county (district), township (town) level of people's government lead to implement the measures to scientific and technological progress, by the examining and assessment of the one higher-level's government", ${ }^{12}$ which helps to supervise the basic level of scientific and technological activities greatly benefitting the whole society's technological progress. The system of examination and assessment in the "Hubei Scientific and Technological Progress Regulations" is extended to the assessment of technological innovation and the service performance of scientific technological research and development institutions, which are established with financial funds, contributing to the effective use of resources and institutions innovation. Both Xiamen and Guizhou have taken note of the specialty of agricultural science and technology. They emphasize practice, competency-based assessment criteria of agricultural scientific and technological personnel.

\subsection{Scientific and Technological Researching Development and Application}

"Scientific and technological researching development and application" contains a very broad reference literally, while the "Scientific and Technological Progress Law" and some other local legislations, mainly refer to the core measures that government and its administrative departments adopt. These encourage scientific and technological progress, emphasize important areas of scientific and technological progress, realize public service system's founding, and outline proposals of industry-university-research cooperation. Taking importance and universality into account, this article selects: a) development of modern agriculture, b) technology public service system's founding, and c) researching and learning combined with industrialization for analysis.

9 Article IX, "Shanghai Scientific and Technological Progress Regulations".

10 Article XI, "Hefei Scientific and Technological Progress Regulations".

11 Id. at Chapter VI.

12 Id. at Article 31. 


\subsubsection{Development of modern agriculture}

Agriculture contributes significantly to the national economy. As such, hosts of local legislations incorporate special articles specific to agricultural technology activities, apart from Shenzhen. Among them, local legislations like the "Guizhou Scientific and Technological Progress Regulations" include a special chapter on how to develop agricultural and livestock technology. Yet a number of laws and regulations directly repeat the content of higher-ranking laws, or violate the inherent requirements of laws. For example, some may contain too many details about agricultural development goals, such as "qualified", "effective", "latest" and other words, but inadequately address how to achieve these goals. Of course, there are some operational provisions worthy of being learned. Two examples include: firstly"the proportion of special financial support to agriculture for agricultural science and technology development and technological achievements promoting should not be less than 40\%" in Hefei's legislation, ${ }^{13}$ guaranteeing the development of agricultural science and technology activities effectively; and secondly a requirement set for Hubei governments above the county level and relevant departments that they "organize agricultural applicable training" to avoid pursing high-tech technologies blindly, and to maximize the economic and social benefits from their actual agricultural and rural situations. ${ }^{14}$

\subsubsection{Founding of technology public service system}

Technology public service system, also known as public technology service system, ${ }^{15}$ includes science and technology resource services, technological innovation services, technology management services, etc. ${ }^{16}$ Various provisions relating to "technological innovation in public service platform", "science and technology intermediary service organizations", "public technology platform, research and development institutions",

\footnotetext{
13 Id. at Article 30.

14 Article XIX, "Hubei Scientific and Technological Progress Regulations".

15 Xie Lijiao. The science and technology service for the general public and its system building. Forum on Science and Technology in China $\square$ 2009(12), p11.

16 Zhang Yun, Lu Xiaocheng. The Status-quo, Problems and Strategies of Technology Public Service System Construction in Beijing. Urban Insight, 2010(5), p8.
}

"basic scientific platform" and "scientific and technological resource sharing mechanism" all belong to the technology public service system generally. They reflect that the concept of a technology public service system has not reached consensual acknowledgement on its connotation, denotation and constituents among legislative academia of "Scientific and Technological Progress Law", so the use of a technology public service system is largely random and excursive. Additionally, the overall structure of the technology public service system has not been formed. Only the chapter "technology innovation platform" in the "Chongqing Scientific and Technological Innovation Promoting Rules" comprehensively stipulate the five aspects -- researching and developing platform, intermediary services, infrastructure and resources open sharing mechanism, financial and insurance services, and credit system. ${ }^{17}$

\subsubsection{Industrialization cooperated with resear- ching and learning}

Target on industrialization cooperated with researching and learning refers to engaging in research projects jointly, building a variety of R. \& D. bases, as well as exchanging information among enterprises, universities and research institutions. Worthy of promotion is the people's governments in Xi'an that play leading roles to achieve this target, ${ }^{18}$ the potential for small and medium-sized enterprises to participate in research activities through joint-development and co-financing, ${ }^{19}$ Shanghai's legislations clearly stated final goal to guide innovation elements into enterprises to achieve competitiveness; ${ }^{20}$ technological-innovation researching and developing funds established in Xiamen that earmark supporting funds for industrialization combined with researching and learning projects; ${ }^{21}$ and the range of supporting funds used for industrialization combined with researching and learning clarified in Shenzhen's regulations. ${ }^{22}$ However, there are still some controversial ordinances. For example, ordinances in Hefei "encourage universities and researching institutes

\footnotetext{
17 Supra note 6,at Chapter V.

18 Supra note 8,at Article IX.

19 Id. at Article XIX.

20 Supra note 9 , at Article XII.

21 Article 25, "Xiamen Special Economic Zone scientific and technological progress Regulations".

22 Supra note 7, at Article XIII.
} 
establish high-tech and innovative enterprises directly" 23 that go against the intention of the Cooperation, which is to rapidly advance scientific and technological achievements into practical productive industrialization rather than have universities and researching institutions, which ought to prioritize superior intellectual study, undertake the major role in commercial production and management directly.

\subsection{The Subjects Engaged in Scientific and Technological Progress Activities}

Above all, enterprises remain one of the most vital subjects.

Because enterprises act as a core ordination medium in scientific and technological progress activities, the relevant provisions arouse intense attention in local legislations. Content worthy to be learned include: pillar and emerging industries specifically determined in local ordinances that concentrate resources to the advantageous innovation professions; legislators who should consult related enterprise managers and industry association personnel in revising industrial developing policies and plans, ensuring that policies are more in line with actual needs and operations; administrative departments that could give prior approval to enterprises with independent intellectual-property capacity thereby encouraging them to improve the level of intellectual-property ability; administrative departments that should support enterprises to cultivate brands rich with technology, leading to the maximization of technological advantages and increased market value; a technology catalogue regularly published by government departments that guides enterprises to achieve technological progress through embodying Article 40 in the "Scientific and Technological Progress Law"; enterprises, which utilize financial capital to introduce major technology or equipment from foreign countries, should develop programs about digestion, absorption and re-innovation and submit applications to the relevant administrative departments, helping to enhance independent innovation capability of enterprises and save financial resources.

The apparent defect is that the spirit of support to encourage scientific and technological progress is confirmed in legislations while the specific means of encouragement and supervision are unstated. There

23 Supra note 10,at Article XVIII. are seven articles in Chapter III named "technological innovation and enterprise's technological progress" of the "Xi'an Scientific and Technological Progress regulations". All of them include general expressions such as "encourage" and "support" but only two of them clearly state: "referred from the relevant national provisions", and just three of them fail to clarify the specific means of encourage or support.

The overall level of a region's scientific and technologic capabilities is determined not only by large enterprises, but is also dependent on the technological innovation abilities of small and medium-sized enterprises (SMEs). Provisions on technological innovation for them is particularly essential. Most regulations centre on three fields. These are: the innovation funds referred by the host law given to small and medium-sized technology-based enterprises, tax preference given to venture capital firms for investment in high and new technology enterprises, and technological innovation services offered to SMEs by public research platforms and intermediary service institutions. Specific measures to promote the technological innovation abilities of SMEs are inadequate; some merely repeat higher-ranking law without further workable discussion. In contrast, the "Shanghai Scientific and Technological Progress Regulations" can be regarded as a model; it announces that the government of Shanghai is responsible for the arrangements in SME Innovation funding, ${ }^{24}$ it also stipulates that SME Innovation funding is one of the main issues of financing scientific and technological progress at the city, district and county levels. ${ }^{25}$

Scientific and technological researching institutes and universities also play a significant role.

Local legislation generally involves the significance of technological researching institutions and universities when addressing targets on industrialization cooperated with researching and learning or the founding of a technology public service system. And the number and content of articles are consistent with the important role that researching institutions and universities play in local scientific and technological progress. Provisions in Chongqing stated that "higher-ranking education institutions should establish and improve the innovation knowledge system." 26 There are only a few provocations

\footnotetext{
24 Supra note 9,at Article XVIII.

25 Id. at Article 38.

26 Supra note 6,at Article XI.
} 
towards the identification of specific feature colleges and universities, which almost encourage them to play a special role in terms of technological innovation in parallel with scientific researching institutions.

Problems lie in these facets. Local ordinances duplicate the content of higher-ranking law that targets funding for modern research institutions. The lack of specific incentives, such as the steps on how the central support should merge into local science and technology research are limited. Worthy of promotion is that Article XVII in the "Kunming Scientific and Technological Progress and Innovation Regulations" claims that "scientific and technological researching and developing institutions set up by financial fund shall accept the check and modify from science and technology administrative department, and undertake evaluation and assessment from a third party regularly and the results of its research should be made known to public consequently". This provision clarifies the subject being evaluated and the evaluation methods, with a strong operational workability. However, provisions like this are few. Operability is a very important criterion of legislative quality. Laws and regulations which lack operability are difficult to realize because they lack effective implementation criteria. Local regulations aimed at solving specific problems should include the identification of steps towards operability. ${ }^{27}$

Lastly, scientific and technical personnel is the most practical and basal element.

Scientific and technical personnel is included with scientific researching institutions in some local regulations while in other regulations it is divided into a separate chapter that focuses on the rights and obligations of the scientific and technical staff. Scientific and technical personnel engaged in science and technology activities play a fundamental and principal role in influencing technological progress. The integral structure of one region's developing potential relies on the research capability and moral character of the local scientists as well as the overall knowledge structure and technological level. To improve the quality of scientific and technical personnel it is encouraged that science and technology personnel exist in every local regulation. Laws and

27 Shi Jiansan, Wu Tianhao. The analysis of local legislation: current situation, issues and solutions--based on the instance of people's congress of Shanghai city. Legal Science, 2009 (6), p100. regulations should include: that legislators distinguish between the different types of scientific and technical personnel to improve the evaluation system of professional titles in order to rule that the technology promoting effect is the main indicator of appraising a professional title for the agricultural technology personnel working in rural areas; a broad scope of scientific and technical personnel to emphasize young-people training and give play to the technological innovation capacity of retirees; an extension of higher-ranking laws' content in order to develop a government sector (or other units) talent training plan and to earmark the proceeds of job-related technology achievements centered on enhancing research capacity; supplemental specific mechanisms for higher-ranking law to add judgment procedures when bearing scientific and technological research failure is used; the effective motivation of scientific and technical personnel, such as supporting young scientists to engage in research activities through arrangements with the Natural Science Foundation, rewards, etc., and encouragement for employee-developers to continue their scientific and technological research, according to distributed stock rights, to offer awards, and so on. Encouraging college graduates, devoted to grassroots work or entrepreneurship, to establish and improve the social service system of scientific and technical personnel rational flows should also be included.

\subsection{Safeguard Measures}

Safeguard Measures are not divided into the same scope among local legislations. The provisions do not entirely correspond to the high-ranking law, in that financial and social capital investment act as primary safeguards measures in all regulations. Some safeguard measures in local ordinances even involve the technology decision-making advisory system, large-scale equipment procurement and evaluation systems. Other measures just revolve around capital investment. This article selects capital investment safeguard measures and other safeguard measures in two parts, for analysis.

\subsubsection{Capital investment safeguard measures}

Technology funding is the basal guarantee to promote scientific and technological progress. Ensuring the proportion of financial investment and encouraging increased social investment funding could be consi- 
dered the two major types of attitudes towards technology funding sources in local legislation. To ensure necessary financial investment is to ascertain financial investment proportion, investment subject, investment object, investment monitoring and the establishment of an effective evaluation system. Problems in legislation lie, in the first place, in the illegibility of financial investment proportion. A financial investment ratio is of significance, but is only identified in Xiamen, Kunming, Shenyang and Hefei's regulations. The reason for this current situation is that the determination of the proportion of investment might be blocked by local financial capacity, departmental interests and other practical problems. Even if this question is put forward, it will be obstructed during the formulating-draft process. Additionally, the using-scope of special funds is too broad; covering almost all scientific and technological domains in multiple regulations, which do not reflect the micro characteristics of local technological developments and the disperse effect of limited financial resources.

Encouraging social investment refers mainly to guidance by governments, participation of financial institutions and the establishment of special funds. Effective safeguard measures include: government participation in the foundation of venture capital funds, guiding social capital flows to venture enterprises; government involvement in the establishment of re-guarantee institutions to support business innovation activities, etc. However, these means are not sufficiently workable for a number of reasons. For example, incentives to financial institutions are not defined, that is to say, there is no benefit-oriented intervention and no mobilization of financial instruments. Regulation in Guizhou claims that "establish scientific and technological innovation of credit guarantees, insurance, chattel mortgage, third-party guarantees and risk-sharing compensation mechanism to encourage financial institutions to transparent technology innovation"28, which along with the supporting implementation measures need to be clarified to ensure implementation success. Additionally, incentives for other bodies that engage in scientific and technological activities are lacking, making it difficult to mobilize wider social forces into scientific research and technological innovation.

\subsubsection{Other safeguard measures vary both in}

28 Article 41, "Guizhou province Scientific and Technological Progress regulations".

\section{number and forms.}

In addition to financial funding, other various safeguard measures can be concluded as follows: 1. the establishment of independent innovation products in government procurement systems; 2 . the foundation of network platforms to include a variety of information technology resources, especially the research projects information sharing system in Shanghai, avoiding duplication of the project application and reducing the waste of resources in science and technology. ${ }^{29} 3$. Supporting of technology infrastructure and major scientific projects through reducing urban construction fees, for example, the local government of Chongqing confirms this measure in the form of legislation; 4. Promoting innovation by rewarding activities in science and technology or individuals, such as the regulations in Chongqing that clearly defined the awarding criteria for high-tech enterprises, innovation companies, as well as new product projects at the national and provincial levels. Some places promote innovation by encouraging intellectual property, but attention should be aroused to distinguish between the different types and nature of intellectual property rights. It's inappropriate to involve trademarks or geographical indications that cannot effectively improve technological progress in award scope.

\subsection{The legal liability}

Clauses on legal liability reflect mandatory and compulsory laws, so they are included in the vast majority of local regulations. The "Chongqing Scientific and Technological Innovation Promoting Rules" doesn't contain such a clause, which is a major disadvantage to it. Other regulations generally follow the higher-ranking laws and expand this content limitedly according to local conditions. It's encouraging to see that these extensions improve the legal liability system of science and technology law. Firstly, they have answered what actions are illegal. "Scientific and Technological Progress Law" only involves the illegal use of financial funds, illegally purchased equipment, hindering scientific and technological activities, plagiarism of technological achievements, cheating for science and technology awards, as well as the legal liability of administrative departments and personnel. In addition, local ordinances extend the list to include

29 Supra note 9, at Article 41. 
governments that avoid purchasing independent innovation products even if they should; the incomplete procedure of introducing advanced technology from foreign countries by the use of local financial funds; the failed examination of technological progress, and so on.

The type of legal responsibility and the means which is undertaken are also significant. Convicting and sentencing in scientific and technological progress law generally refers to the relevant laws about administrative, civil and even criminal responsibility. Special forms of responsibility in the "Scientific and Technological Progress Law" could be restricting certain principal parts' qualification in order to engage in certain activities, such as restrictions on the financial support of researching projects and financial awarding limitations. Local legislation follow these forms, and in particular regulates that some illegal behaviors should be recorded into credit files by the relevant administrative departments.

\subsection{Supplementary}

Most regulations only contain provisions about implementing the date of each ordinance, while Xiamen and Shenzhen include further refinement on the regulations. For example, the "Shenzhen Special Economic Zone Scientific and Technological Innovation Promoting Regulations" provides that "the municipal government or relevant departments shall formulate specific measures for implementation of the provisions of Article 9, 11, 16, 18 within ten months from the date of implementation of this regulation" ${ }^{\text {" }}$, which ensures the implementation specification and realization of the purpose of the legislation.

\section{Proposals on revising local legislations OF SCIENCE AND TECHNOLOGY PROGRESS}

Interpretation of the above suggests that although the newly revised local legislations of science and technology progress are much more rational and suitable for local conditions than those implemented prior to 2007 , there remain some defects-repeating in the specific provisions with the higher-ranking law, coinciding in content with the same-ranking law, the lack of in-

$30 \quad$ Supra note 7, at Article 22. novation and workability, and so on. Legislators should pay full attention to all aspects of the scientific and rationality of the legislative process, and then local laws could play its due role. Only if we stress formulated ways of thinking, establish a formulate-drafting body, and include technical specifications of the provisions and concrete content of the regulations will the quality of the local legislation of science and technology progress be promoted.

\subsection{Clarify the formulated ways of thinking}

Being closely linked with science and technology policies is one overt characteristic of ordinances in the science and technology domain. Apparently existing national laws and local regulations contain detail directly from science and technology policies. Policies usually inflect current dominant officials' ideas, so it is often modified and always more concerned about the short-term revenue-generating technology area, especially given the high-speed development of a market economy. So legislation based on policy is inevitably inclined to focus on economic value, more specifically those areas that could quickly generate income. It's also natural that people modify legislation followed by policy adjustment, which sharply reduces the modification cycle of regulations and damages the authority and stability of law. Importantly, there should be two types of sources to progressive science and technology regulation. In addition to science and technology policy, rational knowledge and a regular pattern of science and technology are extremely vital. However, currently legislators tend to transplant policies, especially the latest ones into legislations while ignoring established and emerging technological developing patterns. In order to sustainably and healthily safeguard scientific and technological progress, and comprehensively promote social development, it's necessary to legislate scientific and technological law impersonally and rationally, and to reflect scientific and technological development regularity in the relevant laws and regulations.

To clarify the formulated ways of thinking, the most fundamental and important provisions of local scientific and technological development should be stated. Regulators should strive to avoid following the latest technology policy blindly but rather work towards ensuring that their efforts are in accordance with rational knowledge and regular patterns of local scientific and technological development, aiming at achieving the combination be- 
tween regularity and policy. The determination of which area(s) to focus on or invest in, to maximize the development of science and technology, regulators shouldn't merely track the latest trend or macro technology policy, but also emphasize the local conditions of technological development and the environment. Regulators should pay attention to not only the industrial areas, which bring direct economic benefits, but also focus on the field of science and technology that research and industrialization rely on. Only in this way can the local technology be elevated effectively and solidly.

\subsection{Select formulate-drafting body carefully}

Formulate-drafting body of local legislations of science and technology progress usually consist of the local people's congresses, the local administrative departments of science and technology, academic researchers, etc. To ensure the quality of the legislation, the selected formulate-drafting body should abide by two aspects: knowledge and attitude. On one hand, a participating revising law should have the correct and systematic knowledge structure. Legislators, to meet the specifics of scientific and technologic legislation making, should not only have a solid theoretical foundation of law and legislative experience, but also master the regular pattern of science and technology development as well as have the rational knowledge for science and technology practices. Only in this way can ordinances combining regularity and purpose in nature be created. On the other hand, the formulate-drafting body should develop the impartial and rational attitude. Currently, legislators aim to achieve a particular industry sector's or department's interest against the camouflage of drafting specific provocations or ordinances. They do this to strengthen or expand the scope of one department's authority, the ordinance set up a variety of rights- jurisdiction, approval, granting license, and so on. ${ }^{31}$ Therefore, the local people's congresses' formulation of local science and technology progress legislation should not be entrusted to one, or just a few, local administrative departments. Rather, regulators should increasingly turn to professors, legal advisors and technology experts as well as listen to the views of representatives of the people. The formulation of local legislation will thereby exert a positive influence on scientific and technological

31 Feng Lixia. The analysis of selfish departmentalism in the administrative legislation. Chinese Cadres Tribune, 2005(8), p31. progress broader than particular sectional interests.

\subsection{Standardize the expression of clauses}

It's common to find expressions in local legislations that violate legal term practices from the existing text, which indicates that the skill levels of local legislators need to be improved. For example: the direct use of simplified names for terms in the legislative text such as "agricultural science institute" is not used in articles, but ASI as a abbreviation is directly used; the utilization of spoken expressions or policy terms, such as "one percent", "innovation and entrepreneurship"; ambiguity caused by improper statements, such as this clause which states that "experts, scholars and business representatives who municipal government employed shall provide decision-making advice in the city development planning, major scientific and technological project approval, scientific research, technological innovation, technology industrialization", which doesn't clarify whether it is the government's obligation or the expert's; the use of non-legal standard terminology, such as "must"; and use of terms in different clauses towards the same problems that vary from one to another, and randomly, for example, when it comes to proportion of financial investment, "budget expenditures", "disposable revenue" and "general budget expenditures" that reflect various calculation data.

The expression of clauses should be accurate and logical, which should be strictly distinguished from general expressions in ordinary life and policy language. Legislators are supposed to avoid all kinds of language problems and elevate the legislative level in the formulated-drafting process. Practically, "legislative technical specification (Trial)" issued by the Standing Committee of National People's Congress should be consulted with, and the use of legislative terms ought to match higher-ranking law.

\subsection{Build specific institutions}

"Generally local regulations lack of specific provisions at supervision and indemnification", ${ }^{32}$ undermine science and technology progress. To improve the

32 Shen Muzhu, Ban Xiaohui. Research About The Creative Legislation For Local Science In China At The Age Of Post-Crisis. Law Science Magazine, 2010(6), p31. 
quality of legislation, specific institutions of the ordinances should be built in two ways. One is to develop incentives and safeguarding systems. As mentioned above, there are some problems in the existing regulations, such as unspecific incentive means, ambiguous guarantee regulations and the repeated contents from the higher-ranking laws. So "incentive" and "support" should not only be indicated in the later legislation, but also be clearly stipulated in implementation objects and basic methods. Or the later legislation could simulate the clear and specific measures for subjects to implement each ordinance and deadline in the "Shenzhen Special Economic Zone Scientific and Technological Innovation Promoting Regulations". This is especially significant in the matter of financial investment, as one core safeguarding measurement should be clearly stated in the "proportion-distribution". Second is to complete norms about responsibility. As already pointed out, it's quite limited for the existing local regulations to illustrate the legal liability of higher-ranking law. Efforts should be made to closely correspond legal liability with illegal behavior that could impede technological progress, which would be punished unconditionally. Simultaneously, the enforcement body should be clearly defined to fight against crimes whose are supposed to be empowered equaling to the ability; and refresh the form of accountability, so as to govern and awe effectively.

\subsection{Focus}

To ensure system integrity, the majority of the existing local legislation of science and technology progress imitate the higher-ranking law structurally and repeat its provisions, contributing to the similarity in these local legislations, which can be applied regardless of local characteristics. Apparently, legislators have not yet recognized the proper function of local laws and regulations. In addition, the advantages of such "regulations" or "approaches" haven't been taken into consideration. To begin with, the structure of local regulations can be simple and flexible without stiff requirements in structural integrity and systematic complex. Legislators should begin with field research to solve the exact problems hindering local regulatory development. For example, local institutions that acquire a strong military-scientific ability on how to build a dual-use platform between military and civilian technology and how to address the issue of secrecy and the distribution of benefits shall be a key topic during the drafting of legislation. Additionally, prior and essential issues should be emphasized and only the workable measures included in local regulations. For instant, there's no necessity to involve issues about reform in scientific research institutes or legislative rights of tax systems in local legislations, which are difficult measures to effectively develop at a few local regulations during such a short time. However, incentives or protection measures are welcomed to be discussed in ordinances, according to diverse technological resources and the financial capacity of each place.

\section{Conclusion}

For the purpose of scientific and technological progress, leading to eventual regional economic and social development, and adaption to integrity of the socialist legal system, legislative bodies in local places are bound to modify and revise local legislations of science and technology progress. A total of 36 local legislations have been developed since the "Scientific and Technological Progress Law" had been implemented. They have been advanced in many aspects including legislative idea, legislative procedure, specific content, etc. However, multiple defects still need to be improved. Legislators should pay full attention to all aspects of the objectivity and rationality of the legislative process. In order to solve the exact problems impeding local regulatory development policy makers should select formulate-drafting bodies, standardize technical specifications of provisions, ensure concrete content of regulations, and build specific institutions of supervision and indemnification in conjunction with legal liability. Only in this way shall the quality of local regulation be promoted, making the local legislation of science and technology progress a basic norm to achieve scientific and technological advancement. 
Para publicar na Revista de Direito Internacional, acesse o endereço eletrônico www.rdi.uniceub.br ou www.brazilianjournal.org.

Observe as normas de publicação, para facilitar e agilizar o trabalho de edição. 